University of Nebraska - Lincoln

DigitalCommons@University of Nebraska - Lincoln

Faculty Publications and Creative Activity, School of Art, Art History and Design

Art, Art History and Design, School of

2002

\title{
Taverns in Nuremberg Prints at the Time of the German Reformation
}

Alison Stewart

University of Nebraska-Lincoln, astewart1@unl.edu

Follow this and additional works at: https://digitalcommons.unl.edu/artfacpub

Part of the History of Art, Architecture, and Archaeology Commons

Stewart, Alison, "Taverns in Nuremberg Prints at the Time of the German Reformation" (2002). Faculty Publications and Creative Activity, School of Art, Art History and Design. 2.

https://digitalcommons.unl.edu/artfacpub/2

This Article is brought to you for free and open access by the Art, Art History and Design, School of at DigitalCommons@University of Nebraska - Lincoln. It has been accepted for inclusion in Faculty Publications and Creative Activity, School of Art, Art History and Design by an authorized administrator of DigitalCommons@University of Nebraska - Lincoln. 


\title{
Taverns in Nuremberg Prints at the Time of the German Reformation
}

\author{
Alison Stewart
}

During the sixteenth century, representations of taverns and inns increased in both prominence and number within the visual art of northern Europe. From Hieronymus Bosch to Pieter Bruegel, painters and designers of prints made images employing taverns and inns as the setting for religious and secular subjects. ${ }^{1}$ Bosch's panel painting of a traveling merchant, variously titled the Wayfarer, Peddler, and the Prodigal Son, from ca. 1510 (Figure 1), includes one of the earliest renderings of the tavern or inn in European art. ${ }^{2}$ Traditional interpretations of the work's subject as the Prodigal Son underscore the religious and moralizing meanings both painting and inn have held within the discipline of art history. ${ }^{3}$

The Prodigal Son "wasting his substance in riotous living" (Luke 15:13) undoubtedly offered fuel for visual thought in such imagery. ${ }^{4}$ In Bosch's painting. the man with tattered clothing, bandaged leg, and basket on back walks to the right while looking back over his shoulder toward the inn, with what may be longing, even regret. Bosch's inn stands in a partial state of disrepair. The roof

Research for this essay was supported by the Department of Art \& Art History and the Hixson-Lied College of Fine and Performing Arts at the University of NebraskaLincoln. Parts of this essay appeared earlier in my "Paper Festivals and Popular Entertainment. The Kermis Woodcuts of Sebald Beham in Reformation Nuremberg" in Sixteenth Century Journal 34 (1993), 301-50.

1 For Netherlandish images of taverns in religious settings, see L M. Kavaler, Pieter Bruegel: Parables of Order and Enterprise (Cambridge, 1999), especially 152, 154, 185, and 189; K. Renger, Lockere Gesellschaft: Zur Ikonographie des Verlorenen Sohnes und von Wirtshausszenen in der niederländischen Malerei (Berlin, 1970). Renger identifies many inn scenes as representations of the Prodigal Son.

2 For Bosch, see W. Gibson, Hieronymus Bosch (New York, 1973). 103-4: C . de Tolnay. Hieronymus Bosch (Basel, 1937), figure 88; P. Reuterswärd, Hieronymus Bosch (Stockholm, 1970), figure 38.

3 On the Prodigal Son, see Renger, Lockere Gesellschaft, and W. Stechow, "Lusus Laetitiaeque Modus," in Art Quarterly 35 (1972), 165-75; For late sixteenth- and early seventeenth-century paintings, see Stechow, "Lusus."

4 Stechow, “Lusus," 165. 


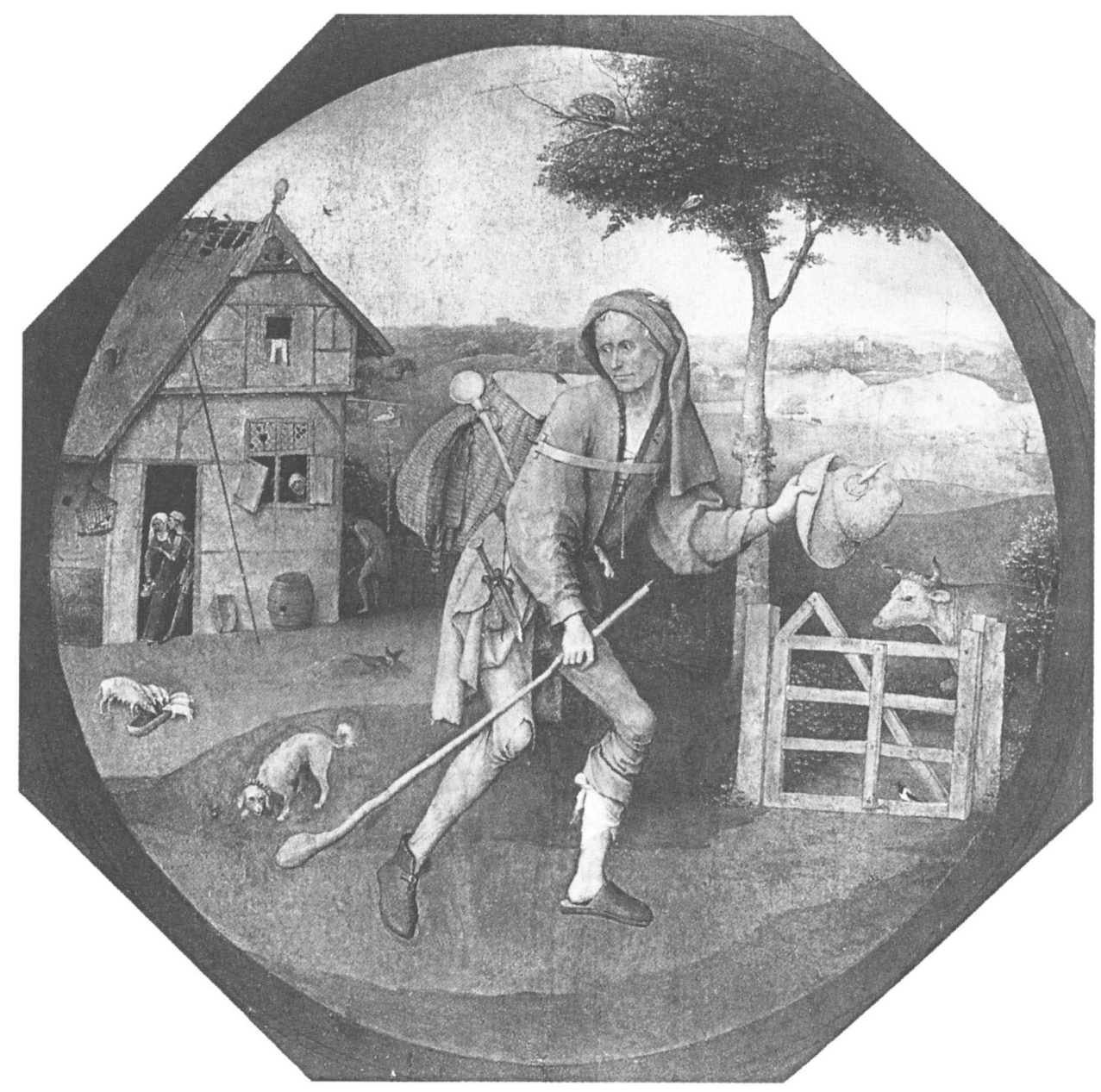

Figure 1. Hieronymus Bosch, The Wayfarer. Oil on panel, ca. 1510-20 (Courtesy Museum Boijmans Van Beuningen, Rotterdam). 
and windows are riddled with holes and one window shutter hangs precariously from a hinge.

Art historians have interpreted Bosch's inn as an emblem of moral degeneration based on its physical decay, ${ }^{5}$ yet the fabric of the building appears intact. In the doorway of the inn the man fondling the breast of the woman and the man urinating around the comer support the moralizing interpretation. In addition, the pigs eating from the trough in front of the doorway appear to identify the man at the center of Bosch's painting as the Prodigal Son-seen, for example, in Albrecht Dürer's engraving of the subject from ca. $1496 .^{6}$ Art historians have, in sum, viewed the tavern - and its more ambitious counterpart, the inn - within sixteenth-century Northern art as a locus of negative behavior whose representation elicited a moralizing interpretation from the viewer.

This essay expands this traditional moralizing and negative approach to public houses by investigating images of taverns designed by Sebald Beham, a pupil of Dürer in Germany. Published in Beham's home town of Nuremberg between 1528 and 1535 as woodcut prints, the works have as their subject kermis (Kirchweih), which was centered around a tavern or inn in the sixteenth century. ${ }^{7}$ Kermis was the most popular peasant festival during the late Middle Ages and Reformation period and it celebrated the anniversary of either a church's consecration or saint's day. In Beham's kermis images, the exterior of a tavern provides the setting for celebrating by peasants and a few members of other social classes. In this essay, Beham's Large Kermis woodcut (Figure 2), the physically largest and most complex example of the theme, will be explored for the variety of meanings and associations the tavern held in sixteenth-century Germany and that reach beyond art history's traditional moralizing approach. I argue that art historians need to consider a wider range of sources and associations when considering the tavern, including those relating to eating and drinking, social gatherings, and peasant festivals. Only then will tavern and kermis be viewed neutrally if not joyously.

For Beham, I would suggest, the tavern becomes the setting and symbol for celebrating and drinking, and for the body with its various historical meanings.

5 Renger, Lockere Gesellschaft, 90; Gibson, Hieronymus Bosch, 103.

6 This print is reproduced in W. L. Strauss (ed.). The Illustrated Bartsch, vol. 10 (New York, 1980), 25 (no. 28).

7 Here I investigate the exteriors of taverns. Beham's Spinning Bee woodcut from ca. 1524 illustrates a tavern interior as does Erhard Schön's Peasant Wedding Celebration from 1527. For illustrations, see M. Geisberg, The German Single-Leaf Woodcut: 15001550, rev. and ed. W. L. Strauss (New York, 1974), nos. 154 and 1171; for discussion, A. Stewart, "The First Peasant Festivals: Eleven Woodcuts Produced in Reformation Nuremberg by Barthel and Sebald Beham and Erhard Schön, ca. 1524 to 1535" (PhD Columbia University, 1986), 254-331 and 226-64. 
Rather than one moralizing meaning, the tavern had a complex range of meanings that requires understanding the historical and social setting of the images' making. Reformation Nuremberg. Beham's tavern and kermis images are integrally linked to the new institution of the Lutheran religion in Nuremberg, officially adopted by the city in March 1525 after several years of gradual acceptance. The tavern in Beham's Nuremberg prints becomes a multivalent image whose various associations add to the richness and complexity of meaning for Beham's kermis prints. The tavern thus serves as an important focal point and nexus of meanings. ${ }^{8}$

In this essay, then, taverns and inns are discussed within the context of kermis and drinking, and a complex range of contemporary responses to these social practices. Emphasis will be placed on what we can learn about taverns from contemporary documents, and the attitudes toward taverns and drinking reflected in legislation issued by the city of Nuremberg, in proverbial expressions, and in carnival plays. The role of the clergy at kermis and taverns will also be discussed, as will Erasmus's Book of Inns; proverbs and carnival plays; animal symbolism; early modem drinking practices; the four effects of wine; and scatological humor. Because drinking at taverns brought with it expulsion from both the upper and lower body, a re-thinking of another art historical response, revulsion, is encouraged and contrasted within a contextual reading of scatological imagery (in accordance with attitudes of the time). In this way, Norbert Elias's "civilizing process" and ideas by other writers on German literature, including the literary figure of Grobianus, will be evaluated.

In the German kermis prints, a prominently placed building can be identified as a tavern by the presence of a pole hung with flag or sign, cloth or pitcher. In the Large Kermis, Beham places a pole with cloth and covered beaker in a window-like opening over the tavern's door. Cloth and vessel indicate that food and drink are served at the tavern; the cloth appears to be a tablecloth like the one on the table before the tavern's doorway. In addition three closely related kermis woodcuts employ a circle, or a circle inscribed with an $x$, indicating the availability of wine. ${ }^{9}$ In Bosch's Wayfarer, a sign with duck or swan, attached to the side of the building, probably refers to the tavern's name. Nearly a half century later (ca. 1568), Bruegel's Peasant Kermis painting (now in Vienna) makes use of a similar flag over the front door. ${ }^{10}$ Bosch's and Bruegel's Netherlandish paintings ap-

8 For ambiguity of meaning, see E. Muir, Ritual in Early Modern Europe (New York, 1997), 14; for multivalency, Stewart, "Paper Festivals."

9 W. Treue and K. Goldmann (eds.), Das Hausbuch der Mendelschen Zwölfbrüderstiftung zu Nürnberg: Deutsche Handwerksbilder des 15. und 16. Jahrhunderts (Munich, 1965), text vol., 115; H. Bauer, Tisch und Tafel in alten Zeiten: Aus der Kulturgeschichte der Gastronomie (Leipzig, 1967), 137; Stewart, "Paper Festivals," figures 2 and 6-8. 
pear to draw on the northern European cultural tradition that also gave rise to Beham's German Large Kermis.

A tavern dominates the center of Beham's Large Kermis, before which at least a dozen people talk, drink, and embrace. Above the tavern at left, a castle looms large before the horizon, a possible reference to Nuremberg's imperial castle, or Burg, and to the emperor to whom the city of Nuremberg was directly responsible. Like Bosch's inn, the tavern here has fallen into disrepair and thus can be seen to exist in a state of moral degeneration for its guests. But the tavern is not singled out for decay; the similar dilapidated condition of several secular buildings behind it casts doubt on such a moralizing interpretation. Just as cracks on the tavern could have indicated moral decay to morally driven viewers, they could also have pointed to rural poverty or simply to the building's advanced age to many others. More certain is the fact that Nuremberg's town councillors, the town government, viewed taverns as breeding grounds for undesirable behavior at the time the kermis woodcuts were made. In 1528 the council commanded residents of Nuremberg to go to church and hear the sermon early on Sundays and feast days, and it discouraged residents from visiting taverns and drinking, gambling, and engaging in frivolities and laziness. ${ }^{11}$ The council also forbade dancing in 1532 at all times of the day at taverns and inns, and knives (Stechmesser) were banished from such locations for butchers and their journeymen because of resulting injuries and deaths. ${ }^{12}$ Council members expressed concern that taverns and inns were the site of discussions by Sacramentarians, a religious group more radical than Nuremberg's own Lutheran religion and not allowed in Nuremberg, and by insurrectionary individuals at the time of the Peasants' War. $^{13}$

10 For Bruegel's kermis painting, see W. Gibson, Bruegel (New York and Toronto, 1977), 163, figure 116; R.-M. and R. Hagen, Pieter Bruegel the Elder c. 1525-1569: Peasants, Fools and Demons, translated Michael Claridge (Cologne, 1994), 79 (in color). For Netherlandish prints of the subject pre-dating Bruegel's painting, see Kavaler, Pieter Bruegel, 188-90; H.-J. Raupp, Bauernsatiren: Entstehung und Entwicklung des bäuerlichen Genres in der deutschen und niederländischen Kunst ca. 1470-1570 (Niederzier, 1986), 246-9.

11 Mandate ... wider die Wiedertäufer (n.d. [1528]); Nuremberg, Staatsarchiv, Rep. $63^{2}$ Titel III: Nürnberger Mandate, no. 19a. Gambling and excessive drinking are mentioned in connection with taverns in Nuremberg, Stadtarchiv, Rep. A6: Mandate, 1529, f. Diiir, although no specific occasion for these problems is included. For texts of both, see Stewart, "First Peasant Festivals," 215 n., 217, and 218.

12 Nuremberg, Stadtarchiv, Rep. A6: Mandate (8 April 1532). For kermis, see Nuremberg, Staatsarchiv, Rep. 63-la: Nürnberger Mandate, Bd. A, no. 86 (26 May 1548).

13 Nuremberg, Staatsarchiv, Rep. 63-la: Nürnberger Mandate, Bd. A, no. 29 (19 January 1532); L. P. Buck, "The Containment of Civil Insurrection: Nürnberg and the Peasants' Revolt, 1524-1525” (Ph.D. Ohio State University, 1971), 54. 


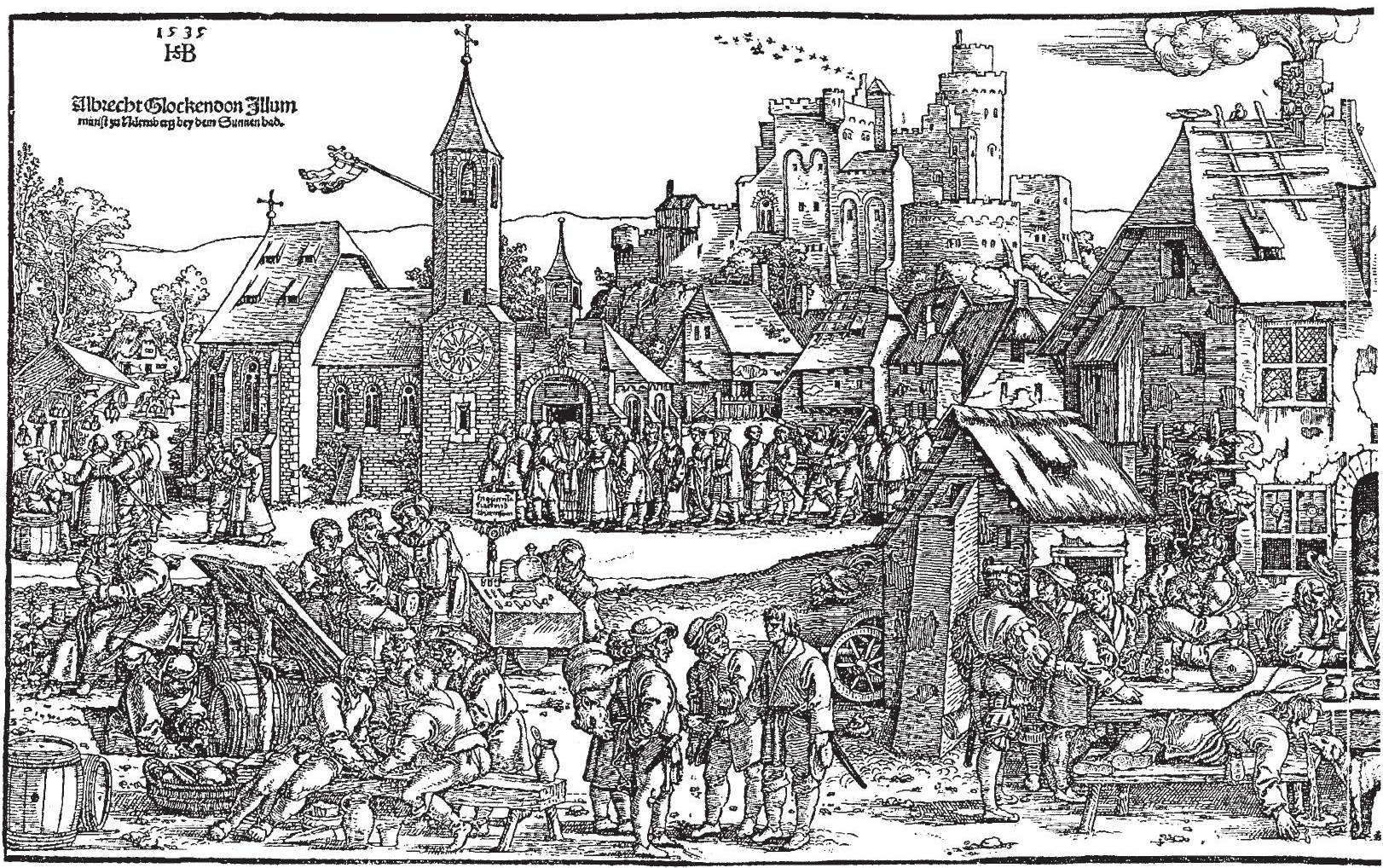

Figure 2. Sebald Beham, Large Kermis. Woodcut, 1535 (Courtesy Ashmolean Museum, Oxford). 


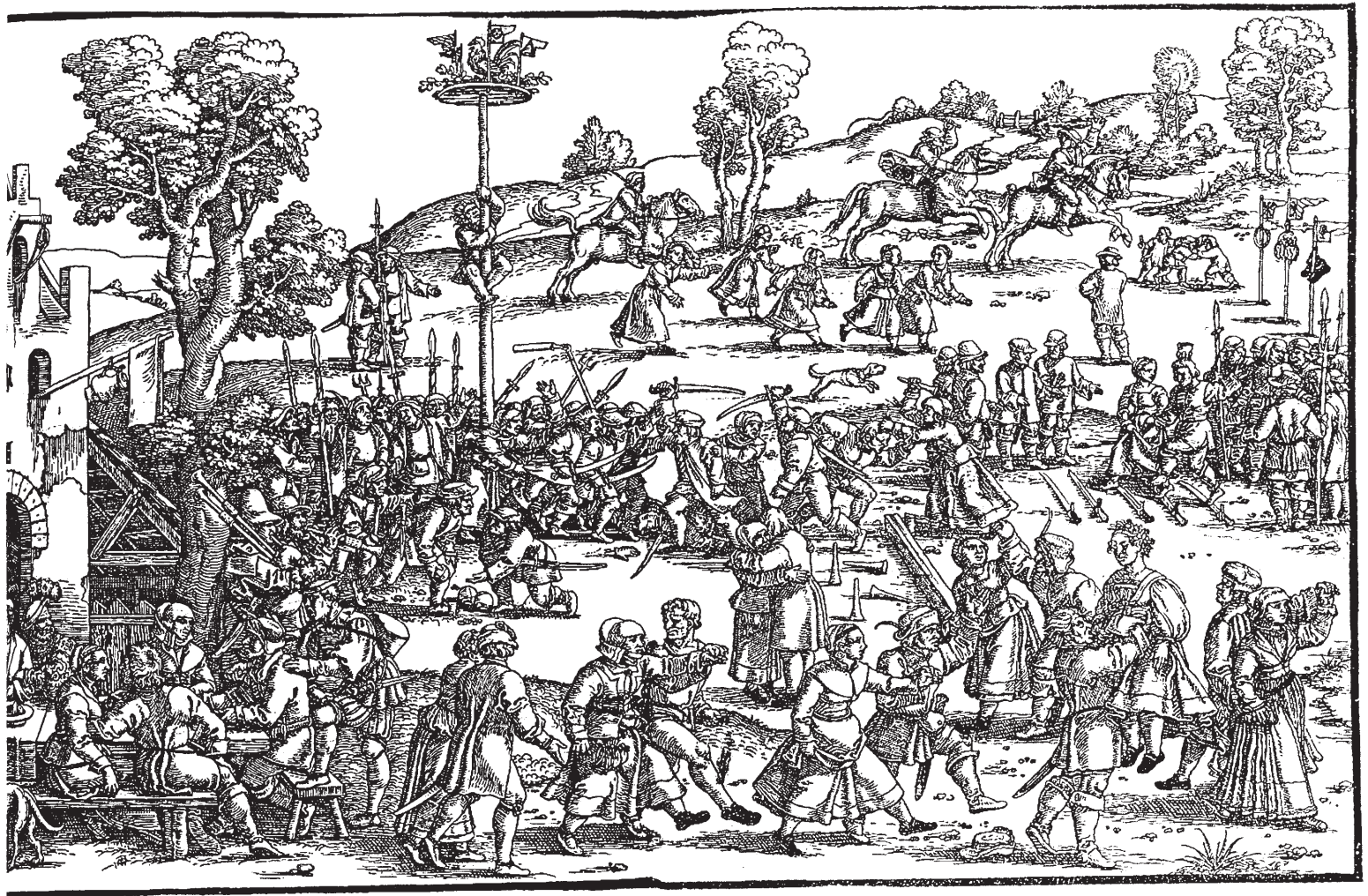


Yet, it is important to keep in mind that these views are those of the authorities constituting Nuremberg's official culture, which, although governing all of Nuremberg society, comprised but a small fraction of the population. The tavern undoubtedly served a greater function in society than as center of gambling, stabbing, and as a meeting place for religious and social radicals. In fact, the functions of public houses across England and Europe were broader and more positive, including the provision of space for people to gather in general and at kermis and other carnival-like celebrations, and for conducting commerce. ${ }^{14}$ Public houses also served as sites for the performance of carnival plays inside and outside Nuremberg. ${ }^{15}$ Socially, German taverns and inns were broadly based, and included women among innkeepers. Public houses came in larger and smaller sizes, the latter visited by poor and common folk. ${ }^{16}$ The cracked facade of the tavern in Beham's print, then, might point to the low economic status of the innkeeper and village.

Peter Burke views such taverns and inns as a public setting that transmitted popular culture, while Peter Stallybrass and Allon White link tavern and popular festivals in the expression "the tavern and the popular festive scene."17 Although Burke's discussion centers on the English inn, alehouse, or beer cellar, many of the activities that went on in these institutions (card playing, cock fights, and the game of ninepins) are similar to those of their German relatives, thereby validating a comparison. ${ }^{18}$

At Nuremberg, the council issued a variety of printed mandates that offer insights into the council's views on taverns and what it believed took place there. In 1530 council members stated that at the occasion of kermis gangs and crowds were creating disturbances at taverns and inns. According to the town fathers, innkeepers offered prizes for the largest group on the skittles or nine-pins field, or on fields where games of chance were played. In Beham's Large Kermis at right, a skittles field, game of chance below the Maypole, and crowds can be seen. In order to reduce noise and violence, the council commanded that public houses not be visited at kermis in large groups with drums and fifes. ${ }^{19}$ Nuremberg authori-

14 P. Stallybrass and A. White, The Politics and Poetics of Transgression (Ithaca, 1986), 30.

15 D. Wuttke (ed.), Fastnachtspiele des 15. und 16. Jahrhunderts (Stuttgart, 1973), 402.

16 M. Wiesner, Working Women in Renaissance Germany (New Brunswick, N.J., 1986), 133.

17 Stallybrass and White, Politics, 198.

18 P. Burke, Popular Culture in Early Modern Europe (London, 1978), 109.

19 "mit grossen hauffen/auch Trummeln vndd pfeyffen zubesuchen": Nuremberg, Stadtarchiv Nürnberg: Mandate (23 August 1530); and Nuremberg, Staatsarchiv: Nürnberger Mandate, vol. A, 52, no. 24: “Tentz vf dem Land." 
ties also condemned excessive drinking (zechen) at kermis both in this decree and in another mandate of $1537 . .^{20}$

The varied views of taverns and inns and the variety of activities taking place at them point to a broad and popular audience that frequented taverns. In fact, according to the artist-writer Joachim von Sandrart in the seventeenth century, Beham himself owned his own inn at Frankfurt late in life (although recent studies lend no credence to such ownership). ${ }^{21}$ In any case, taverns like the one Beham showcases in his Large Kermis would likely have also served as an indoor site for hanging and viewing prints with the kermis theme. ${ }^{22}$

Nuremberg's public houses provided services far beyond those indicated in the town's council records. We have seen that food and drink were served at Nuremberg taverns. For German inns and taverns in general the availability of wine or beer was indicated by the display of drinking vessels made of iron, by bush or twigs, and by paintings on wood or tin hung before the building. In Beham's Large Kermis, the pole extending from the window specifically denotes the sale of wine as does the circle inscribed with cross in his Kermis (Erlangen) and its two related kermis woodcuts. ${ }^{23}$ In the Large Kermis, the availability and importance of wine are underscored by the grape vine growing against it on a trellis.

The tavern and table before it form the center of activity in Beham's Large Kermis woodcut (Figure 3). Behind the rectangular table sits a man who, judging from his dress, is probably learned; he is accentuated by the tall arched doorway above his head. He sits behind a rectangular table reminiscent of Last Supper imagery, such as Leonardo da Vinci's painting from 1498-99. The placement of a round tray at center, however, visually links Beham's woodcut to northern European imagery of the Last Supper theme, including Dirck Bouts's painting from ca. 1467 and Dürer's Lutheran-inspired woodcut from 1523. ${ }^{24}$ Beham may have deliberately inserted such visual references as a play on earlier Last Supper images, including those by his teacher Dürer. The core component of the

20 For the mandate of 1537, see Nuremberg, Staatsarchiv: Nürnberger Mandate, vol. A, 116, no. 49 (17 September 1537).

21 M. Carroll, "Peasant Festivity and Political Identity in the Sixteenth Century" in Art History 10 (1987), 294; S. Goddard, The World in Miniature: Engravings by the Little Masters, 1500-1550, exhibition catalogue (Spencer Museum of Art, University of Kansas, Lawrence, 1988), 222.

22 Stewart, "Paper Festivals," 347-8.

23 Treue and Goldmann, Das Hausbuch, text vol., 115; Bauer, Tisch und Tafel, 137.

24 For illustrations of Bouts's and Leonardo's Last Suppers, see L. Goldscheider, Leonardo da Vinci (New York, 1959), plate 73, and J. Snyder, Northern Renaissance Art: Painting, Sculpture, the Graphic Arts from 1350 to 1575 (New York, 1985), color plate 25. 


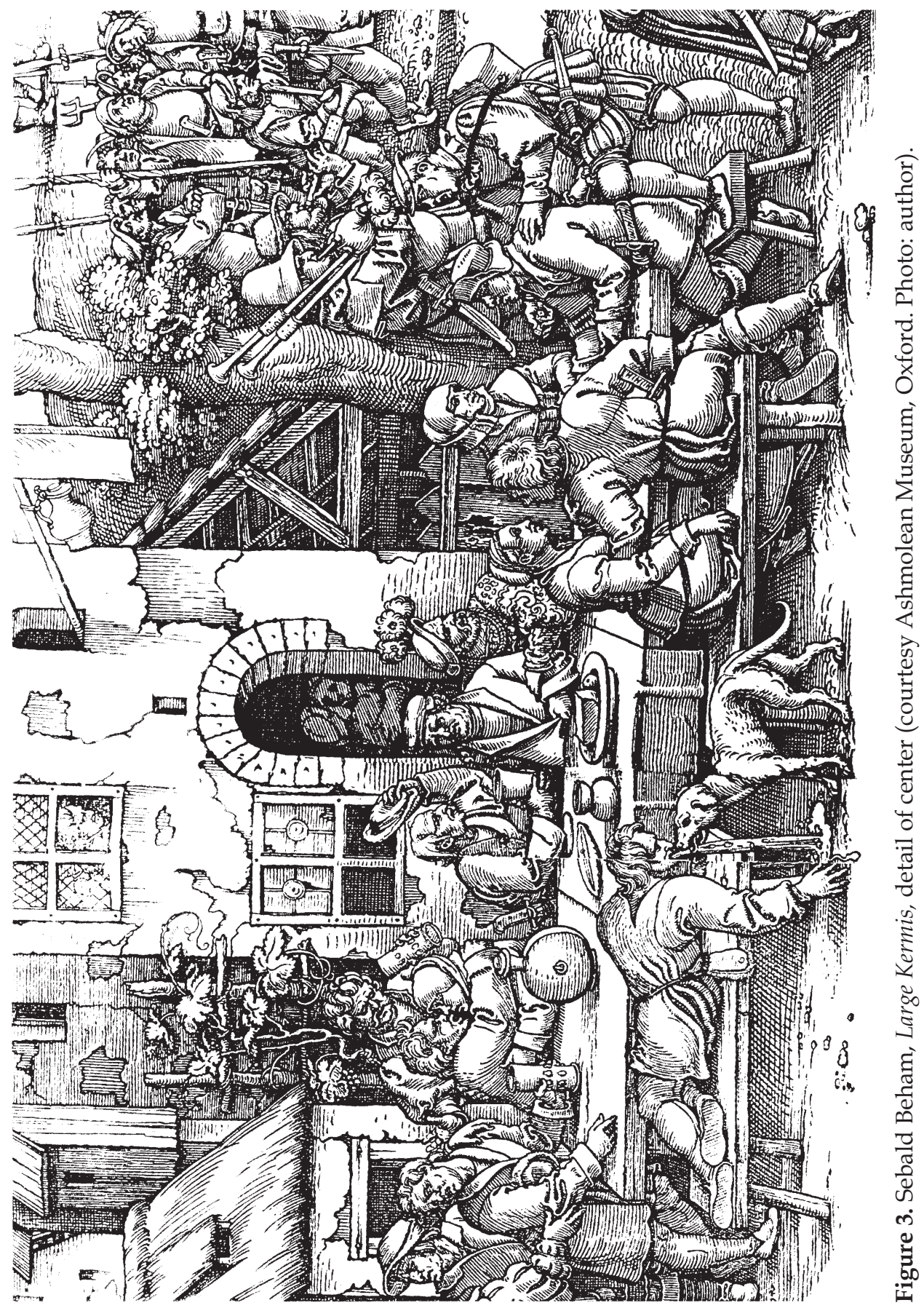


Last Supper, the sacrament and its nature, had earlier been widely debated at Nuremberg taverns and inns, leading the council to prohibit such discussions there. ${ }^{25}$

Beham offers a wide variety of activities before the tavern. At the left end of the table, a man dressed in slashed clothing appears to call the peasant holding a beaker to military service, a function lansquenets from villages served in the sixteenth century. ${ }^{26}$ Judging from the horrified expression on the peasant's face, it is possible that the lansquenet has just informed the peasant of his conscription (or some equally unwelcome news). The male peasant between them, who wears a pointed peasant hat and who places one hand on each of their shoulders, appears to be attempting to reconcile them. To the right, a couple in profile embraces enthusiastically before the grape vine, while the man behind them serves as go-between with the viewer. His gesturing hand and beaker suggest that the wine he holds, produced from grapes and vines like those behind him, contributed to the couple's loving attitude. Another couple embraces within the darkness of the tavern's doorway - reminiscent of Bosch's imagery in Figure 1-and another man seated on the bench before the table places one arm around his companion's waist. She gently touches his shoulder and returns his gaze in a manner now recognized for the sixteenth century as indicating visual intimacy.

Beham underscores the importance of wine and its amorous effects through the trellis and the embraces of these three couples. He includes other effects of wine as well. The man carrying a box or container over his shoulder, at the right end of the table, has been identified as a peddler, ${ }^{27}$ and he offers dice to a peasant man and a more formally dressed woman who show little interest in the offer. In Beham's time, giving in to the lures of betting on dice was believed to be a common result of the enjoyment of wine, as were amorous embracing and vomiting. Gambling was enjoyed across the social classes, even by such well respected members of Nuremberg's community as Albrecht Dürer. Playing cards and coins were found behind wainscoting in Dürer's home, a discovery that not only indicates the enjoyment of gaming in Nuremberg, but also suggests the necessity of hiding evidence of it from the authorities. Gambling was forbidden during the sermon on feast days by Nuremberg's authorities in $1528 .{ }^{28}$ Because kermis was considered to be a feast day in Nuremberg, the authorities would have deemed gambling inappropriate and impermissible, at least during the church sermon.

25 Buck, “Containment," 54; H. Moeller, Die Bauern in der deutschen Litteratur des 16. Jahrhunderts (Berlin, 1902), 101 n. 41.

26 R. W. Scribner, For the Sake of Simple Folk: Popular Propaganda for the German Reformation (Cambridge, 1981), 31, 40.

27 Renger, Lockere Gesellschaft, 89.

28 M. Mende, “Der Maler mit dem Silberblick," in Merian 6 (1981), 70; Nuremberg, Staatsarchiv, Rep. 63-2 Titel III Nr. 19a: Nürnberger Mandate, 1528. 
The fact that the time on the church clock at left indicates eight hours after sunrise, thus after the sermon and in the afternoon, may mean that this was not a problem here-nonetheless, despite its popularity at kermis, members of Nuremberg's elite may well have considered the use of dice unacceptable in the context of a church holiday. Patrician council members who were responsible for penning legislation, along with members of the clergy, might have hoped to reduce the presence of gambling at kermis even while acknowledging its existence.

Seated before the tavern of Beham's Large Kermis are men from several social classes who can be identified by their clothing. In the sixteenth century, class determined clothing and ordinances attempted to keep an individual's dress class-appropriate. ${ }^{29}$ As noted above, a learned man, presumably a member of the clergy, sits before the tavern door; at left, a peasant greets him. They are accompanied by a man dressed as a prince at right. The prince's social position, indicated by his brocaded shirt, wide neck chains, and plumed hat, can be seen in a woodcut by Jost Amman. ${ }^{30}$ The prince touches the clergyman's arm and shoulder suggesting animated talk, friendship, or persuasion. As the peasant raises his hat in respect or greeting, he offers a tumbler of drink to the clergyman, who wears a thick coat with lapels and the standard scholar's headdress of flat hat with short sides. The hat appears similar to one worn by the male dancer at far right and by the bishop of Freising in a portrait from ca. 1528..$^{31}$

The face of this clergyman is similar to Martin Luther's, as depicted in Hans Brosamer's woodcut from $1530 .{ }^{32}$ This print, along with numerous painted portraits of Luther, made the Reformer's features known to the populace. But the clergyman in Beham's Large Kermis could have been seen less as a portrait of Luther than as a general likeness of a member of that religious group for whom the consumption of alcoholic drinks was common among the rural clergy, in particular at kermis. The inclusion of a pastor before the tavern at Beham's Large Kermis carried various associations depending on the viewer.

Clergy regularly attended kermis. Documents indicate that several members of the clergy and a judge sat together at an Austrian kermis in 1525, and members of the clergy were given money for drinking (zechen) at kermis in Lower Franco-

29 For clothing ordinances in Nuremberg, see J. Baader (ed.), Nürnberger Polizeiordnungen aus dem XIII. bis XV. Jahrhundert (Stuttgart, 1861), 65-7, 95-112.

30 J. Amman, Trachtenbuch (Nuremberg: Hans Weigel, 1577), fol. Br.

31 Portrait of Philipp van der Pfalz, Bishop of Freising by Barthel Beham: J. Kettlewell, The Hyde Collection Catalogue (Glen Falls, N.Y., 1981), 72-3.

32 For Brosamer's Luther, see Geisberg, German Single-Leaf Woodcut, no. 423. 
nia, closer to Nuremberg, in $1535 .{ }^{33}$ Members of the clergy (ministers, preachers, and chaplains) in Nuremberg's neighboring territory of Brandenburg-AnsbachKulmbach were also asked in 1536 if they held kermis. This question suggests that members of the clergy may have still sponsored kermis, or at least attended it themselves in their own village, if not in other villages. ${ }^{34}$ The same authorities told the Catholic clergy some thirty years later that they should not go to another village's kermis, thereby underscoring the authorities' intention to limit kermis visits (and possibly the clergy's reluctance to give them up). ${ }^{35}$

Members of the clergy who visited taverns at kermis were probably local rural lower clergy, and not the more prominent and socially conservative members of Nuremberg's urban upper clergy, who vocally criticized and condemned kermis as a secular celebration. In general, pastors were viewed as representatives of social authority and usually possessed greater learning and social status than did parishioners. The prominent placement of such a cleric at the center of the Large Kermis underscores his authority as the local rural pastor, whom contemporaries saw as an extension of the state and reinforcer of moral and social order, as Bob Scribner observed. ${ }^{36}$

At kermis as well as more generally, alcohol consumption was considered a normal part of a clergyman's life. Parishes included wine as one of a pastor's benefits, and clergymen drank alcohol on a daily basis. ${ }^{37}$ In Mögeldorf the pastor also ran the tavern, much to the discontent of the council. In 1524 the Nuremberg council instructed Mögeldorf s pastor to stop selling alcohol or the bottom of his barrels would be smashed..$^{38}$ But the presence of clergy imbibing at kermis could also have been understood by council members as an indication that Bacchusmore than God or the anniversary of the church's consecration - was being celebrated. For others, however, including peasants, drinking at kermis, even by the clergy, was considered a normal and acceptable practice.

33 G. Franz, Quellen zur Geschichte des Bauernkrieges (Darmstadt, 1963), vol. 2, 338 no. 161; K.-S. Kramer, Bauern und Burger im nachmittelalterlichen Unterfranken: Eine Volkskunde auf Grund archivalischer Quellen (Würzburg, 1957), 71.

34 E. Sehling (ed.). Die evangelischen Kirchenordnungen des XVI. Jahrhunderts, vol. 11 pt 1 (Tübingen, 1961); pt 26, 321-1: "Item damach soll gefragt werden der pfarrer [prediger, caplonen] desselben orts, wie hemach volgt: ob er kirchwei und hagelfeier halte."

35 Sehling, Kirchenordnungen, pt 8, 357, “Kapitelsordnung 1565/1578": "Es soil kein priester zum andern auf die kirchweihe gehen, weder an der rechten noch an der nachkirchweihe."

36 Scribner, Simple Folk, 57-8, and n. 63. See Stewart, "Paper Festivals," 332-3, for more on rural clergy.

37 F. Blanke, "Reformation und Alkoholismus," in Zwingliana 9 (1953), 18, 76.

38 Nuremberg, Staatsarchiv: Ratsverlässe 700, fol. 3v (13 Feb. 1524): “Den pfarer von megeldorff sagen das er seins schenckens abste, wie nicht, so wird mon den fessern die poden auss schlahen." 
Perhaps for this reason, Luther and his followers were berated by their opponents for falling short of cleansing ordinary people of the kind of excesses that kermis encouraged. One such opponent was Sebastian Franck, who especially accused Luther of failing to curb widespread drinking. In his On the Horrible Vice of Drunkenness from 1528, Franck complains that being drunk has become the Bible for many Lutherans, and that fasting and abstaining - what he recommends as a cure for drunkenness - are considered sinful and papist. ${ }^{39}$ Franck despised Luther (who returned the sentiment). Luther claimed that Franck's radical spirit was blown into his ear by his wife, Ottilie, Beham's sister. ${ }^{40}$ If Lutherans were viewed as drunkards by Franck and other Spiritualists, the presence of a minister at the center of the Large Kermis might raise the question of whether Beham was criticizing religious men from Nuremberg (i.e., Lutherans) for drinking at all in 1535, no matter how common the practice. On the other hand, although Beham does show the pastor across the table from a drunk peasant, thus in his presence, he does not actually depict the pastor drinking.

In the polemical battle for Protestant support, criticism of Lutherans' excessive drinking appeared in print as early as 1525 outside Nuremberg, where it was not limited to Franck. The Anabaptist Ludwig Hatzer railed against Luther's concept of "evangelical freedom" that praised Satan and boozing. ${ }^{41} \mathrm{Lu}$ ther himself believed that many of his followers misunderstood his concept of "evangelical freedom" as granting carte blanche to the expression of the basest of needs. This failure to comprehend the true meaning of Luther's words is considered one way in which the Reformation indirectly encouraged excessive drinking. ${ }^{42}$ Surely the presence of a pastor at kermis in Lutheran Nuremberg may have indicated to Luther's opponents that kermis celebrators in Nuremberg were drunken Lutherans, or at least that the pastor shown gave tacit approval to such drinking. Keeping in mind, however, that the definitions of "drunkenness" or alcohol abuse in early modem Germany were quite different and more nuanced than they are today, the presence of a pastor in Beham's print could carry a double meaning: at once pointing up the normalcy of kermis drinking, and at the same time, indicating that it fit the description of the Reformer and his "well-known fondness for beer and wine." Luther approved of moderate drinking, which to him could include occasional inebriation, or intoxication, as distinct from more habitual drunkenness (including drunkenness on

39 Blanke, "Reformation und Alkoholismus," 80.

40 D. Martin Luthers Werke: Kritische Gesamtausgabe 58/1 (Weimar, 1883-1948), 219; H. Weigelt, "Sebastian Franck," in Gestalten der Kirchengeschichte 6 (1981), 120.

41 Blanke, “Alkoholismus," 80-81, cites Hatzer's Von den evangelischen Zechen of 1525.

42 Blanke," Alkoholismus," 80-81. 
a daily basis). Thus, Luther condemned only habitual drunkenness, not the occasional indulgence. ${ }^{43}$

But it must be remembered that the Large Kermis was published at Nuremberg, the Lutheran stronghold of south Germany, and that most of the individual printed images, or impressions, of the woodcut from the sixteenth century were required to be identified with both the location of Nuremberg and the publisher's name. For the Large Kermis that meant Albrecht Glockendon within Beham's lifetime, and Hans Weygel in the second half of the sixteenth century. ${ }^{44}$ It seems unlikely, therefore, that a woodcut circulating widely in Nuremberg would be viewed as blatantly critical of the town's religious leader, Martin Luther.

If impressions of the print were distributed outside the imperial city, as I believe they were, then Luther's critics could have seen a likeness of Luther in the face of the pastor seated in the midst of drinking before the tavern. Like John Calvin, Franck supported greater moderation in drink and criticized Luther's "fondness for beer and wine." But in the sixteenth century, particularly in Lutheran Nuremberg, total abstention from drink was a new approach that had not yet become part of the cultural vocabulary. Whereas Calvin, Martin Bucer, and Ulrich Zwingli demanded a strict moral code (perhaps Franck and Beham as well) in which the outward behavior was to conform to one's inner piety, Luther's theology stressed rather the individual Christian's personal relationship with God. That relationship with God included the enjoyment of one of His best gifts, wine and beer. ${ }^{45}$

In 1523, over a decade before the publication of Beham's Large Kermis, Erasmus of Rotterdam published his Book of Inns (Diversoria) and his own account of what must have been a large German inn, judging from the nearly 100 people from all social classes he said gathered in its dining room. According to Edward Muir, "dining rituals" can serve as markers of social identity. Erasmus's account of the inside of a German inn demonstrates Muir's point. When Erasmus describes the eating habits he observed in the inn, he describes those of a rich mix of old and young, men and women, adults and children, nobles and peasants. They ate food from a communal dish into which each person dipped a piece of bread, ate, and re-dipped. This mixing of hands, bread, even saliva in the dish used by

43 B. A. Tlusty, "Defining 'drunk' in early modem Germany," in Contemporary Drug Problems (Fall 1994), 427-51, esp. 437-8, 443-6; idem., Bacchus and Civic Order: The Culture of Drink in Early Modern Germany (Charlottesville, 2001), 48, 72-4.

44 For the various states and impressions of Beham's Large Kermis, see Stewart, "First Peasant Festivals," 400-401.

45 Tlusty, "Defining 'drunk,'” 437, 438, 445. 
all resulted for Erasmus in what Muir calls "the undisciplined mixing of classes, functions, and bodily processes." 46

Here Erasmus views the inn as the site of distasteful experiences involving the mixing of bodily fluids. Erasmus's view is an elite one involving social distancing and attitudes that reveal the "civilizing process" Norbert Elias proposed fifty years ago. According to Elias, Erasmus, other humanists, and members of the secular authorities attempted to effect a social transformation in which the rough customs and manners of ordinary people-i.e. most people-would be smoothed and cleaned up, and made more like those of the elite, who attempted to induce the change. To be civilized meant no more picking one's teeth and nose, defecating, or vomiting before others. ${ }^{47}$ To be civilized meant privatizing one's bodily processes.

Humanists often employed animals to label undesirable human behavior with what Muir called animal-human opposition. Erasmus called the impatient youthful eater a "wolf" in his Manners for Children from 1530: "Some people put their hands in the dishes the moment they have sat down. Wolves do that ...." 48 The dog was also often employed as an emblem of the indiscriminate eater or imbiber. In Italy, Giovanni della Casa condemned slothful eaters in his Galateo from 1558 when he described those "lying like swine with their snouts in the soup, not once lifting their heads and turning their eyes, still less their hands, from the food, puffing out both cheeks as if they were blowing a trumpet or trying to fan a fire, not eating but gorging themselves ...." As Muir observed, this mixing of animal and human "threatened the whole system of distinction made through manners." 49

When humanist-writers and print designers in Germany employed animals in their sixteenth-century visual and textual discourse to underscore human's animal-like habits, both pigs and dogs became popular emblems for gluttony. ${ }^{50}$ By including these animals before a centrally located tavern, Beham marked the building within the humanist tradition as a place where inordinate imbibing took place. In the Large Kermis, such drinking led to the vomiting of one peasant from a bench probably from wine, judging from the nearby grape vines and grapes. The drunken man appears as "drunk as a swine" (voll wie ein schwein), thus visualizing an expression seen also in sixteenth-century woodcuts. The pig alone served as an emblem of gluttony from the Seven Deadly Sins in

46 Muir, Ritual, 127-8.

47 N. Elias, The History of Manners: The Civilizing Process (New York, 1978).

48 Muir, Ritual, 128, here citing Elias, History of Manners, 89.

49 Muir, Ritual, 127. On drunkards as animals, see Tlusty, Bacchus, 54-5, 59-62, 65-7, 74-5.

50 A. Bömer, "Anstand und Etikette nach den Theorien der Humanisten," in Neue Jahrbücher für das klassische Altertum, Geschichte und deutsche Literatur und für Pädagogik 14 (1904), 223-42, 249-85, 330-55, 361-990. 
prints such as Hans Burgkmair's woodcut from 1512 and Jorg Pencz's engraving from ca. $1540 .^{51}$

The pig also functioned as an emblem for the popular sixteenth-century notion of the effects of wine on the drinker. In 1528 Erhard Schön, Beham's collaborator and contemporary, published a woodcut with the subject of the four effects of wine. ${ }^{52}$ Schön visually outlines the different reactions to wine drinking in keeping with contemporary ideas on the four humors or temperaments. The consequences of drink range from reacting as sanguine as a lamb, to as choleric as a bear or as phlegmatic as a pig. Schön shows one phlegmatic man vomiting and two others defecating. Collectively they act like the kind of four-legged pig Schön shows lapping up what the drunkard emits.

The pig here serves as emblem for both swinish behavior in general, and for the phlegmatic temperament in particular. Because of their excess bodily fluids, phlegmatics were believed to lose control of their bodily functions when drunk. ${ }^{53}$ The accompanying text by Hans Sachs, Nuremberg's poet-cobbler, describes such effects of drink on the phlegmatic drinker under the third characteristic of wine: overeating and excessive drinking (fressen, schlampen), drunkenness (trunken und stüdvol), filthy language (Erst lat er die sew glocken klingenn), staggering, lying in filth (bsult sich im kot, wie ein schwein; and Ligt etwan ein wil inn eym mist), belching and farting like a pig (gröltzt und fartzt er wie ein saw), and urinating in bed (villeicht pruntzt er auch in das pett). ${ }^{54}$

Approximately 1528 Beham designed his Kermis at Mögeldorf woodcut, a wide, frieze-like image that begins with a small tavern-like building, bearing a pole with circle and what appears to be a bush. In front of the building a pig consumes filth beside a man who vomits from a bench. Both man and pig serve here as emblems of gluttony probably for the men and women who eat, drink, and celebrate at a wide table, at right. ${ }^{55}$ Shawm and bagpipe players provide music for some fifteen couples who dance to the right.

In the Kermis at Mögeldorf Beham informs that too much drinking and celebrating can result in the kind of swinish behavior shown in the print. This moralizing message suggests that one response to the activities shown could have been revulsion and avoidance of such behavior. In a printed sermon on sobriety from 1539, Martin Luther states that a drunkard should be represented in the form of a

51 On Burgkmair's gluttony print, see Stewart, "Paper Festivals," figure 3. On Pencz's, see Stewart, "First Peasant Festivals," figure 40. Cornelis Anthonisz's Demon of Drink woodcut (ca. 1540) shows a person with beer barrel torso and head of a pig: Stewart, "Paper Festivals," figure 4.

52 Reproduced in Stewart, "Paper Festivals," figure 11.

53 Tlusty, “Defining 'drunk,'” 430; idem, Bacchus, 54-5, 59-60.

54 A. von Keller (ed.), Hans Sachs 4 (Tübingen, 1870), 237, 240-43.

55 For illustrations of Beham's Kermis at Mögeldorf woodcuts from ca. 1528 and 1534, see Stewart, "Paper Festivals," figures 2 and 5. 
pig. ${ }^{56}$ Less censorious responses to such images of expulsion, however, were also possible. Pigs were highly visible and ordinary in urban settings beginning in the sixteenth century. ${ }^{57}$ The pig in Beham's Kermis at Mögeldorf could have been understood in a number of ways including, but not limited to a commonplace animal, emblem of too much drink, and symbol for the sin of gluttony.

But it is important to remember that the potentially moralizing details of men vomiting and sometimes defecating before a tavern functioned on another level that mixed moralizing attitudes with entertainment and delight. German carnival plays enjoyed a long tradition of delighting in scatology as a vehicle for the comic, what Johannes Merkel calls "faecal comic." 58 Calling attention to such expulsion while joking about it is what Sidney Shrager has seen as both a moralizing element and what he calls "scatological satire." 59 More recently, Barbara Correll merges moralizing and pleasurable approaches by referring to the scatological antics of the scandalous figure Grobianus as the "peepshow of civility." 60 Correll underscores that scatology can both call attention to undesirable behaviors while delighting in them, as part of what she sees as the civilizing process explained by Norbert Elias. ${ }^{61}$

For Elias, society's elite and authorities encouraged manners and social graces across class boundaries, advancing what Elias calls the changing "shame frontier." By bringing the effect of drink on the body before a broad audience in his kermis prints, Beham called attention to social problems, attempted to cleanse society of them, and delighted in them as well. ${ }^{62}$

In approximately 1528 Hans Sachs penned a carnival-play like text that appeared above Beham's Kermis at Mögeldorf woodcut; a copy of the woodcut was published in 1534 with slightly altered text. The text describes peasants at kermis

56 "Sauffteüfel ... vnd durchausz eytel Sewleben füret//Das/wenn man es malen solt//so muszt man es ainer Saw gleich malen." Martin Luther, Wider Völlerey ond Trunckenhait, Ausz der Epistel S. Petri (Augsburg: Valentin Othmar, [1539]), fol. Aiiiiv.

57 Stallybrass and White, Politics, 44-59.

58 J. Merkel, Form und Funktion der Komik im Nürnberger Fastnachtspiel (Freiburg im Breisgau, 1971), 192-201. On the related literary tradition in France and what Andrew Cowell calls the "comico-realist" literary tradition, see his At Play in the Tavern: Signs, Coins, and Bodies in the Middle Ages (Ann Arbor, 1999), 1.

59 S. Shrager, Scatology in Modem Drama (New York, 1982), 75-95.

60 Eckhard Bernstein singled out this expression in his review for the Scholars of Early Modem Studies directory, 34 (2000), 99, of B. Correll, The End of Conduct: Grobianus and the Renaissance Text of the Subject (Ithaca, 1996).

61 Correll, The End of Conduct, 107.

62 For an examination of additional images that simultaneously express social critique and carnivalesque humor, see Tlusty, Bacchus, 58-68. 
in colorful terms. The peasants are boisterous, earthy, and eager for drink, love, and a fight. There is an abundance of food and enough drink to cause the intoxication of several peasants who vomit as a result. "Liendl from Ganckhofen, Drank until he was blind drunk" (stanza 9) and Eselsmüller from Potenstein "was the biggest glutton at the table. With Gretel Meyer he rummaged about. And hugged her until she threw up" (stanza 19). ${ }^{63}$

Drink serves a similar role in both text and woodcut. The text encourages gluttonous, drunken behavior, loud and uncontrolled noises, and amorous, if not adulterous encounters. "Wine was drunk in large quantities. Such that many sank under the bench. On this side there was great belching and vomiting, Yelling, singing, shouting, shrieking" (stanza 3). The viewer also learns that Distaff Christen, who dances with Liendl from Ganckhofen, "probably farted (fisten) thirteen times" (stanza 9). Bodily functions of several kinds are repeatedly included in Sachs's Kermis at Mögeldorf text. ${ }^{64}$

Sachs also includes sexuality, aggression and fighting, and anticlerical humor, with the text alone informing that fighting forces the kermis to end, much as it could have in the Large Kermis (at right). Sachs's text must be read in the original German if its humorous aspects are to be best appreciated. The colorful language adds to the humorous, almost farcical tone of the text. Better read aloud in the custom of the time than silently in the modern manner of reading, the rhymed couplets were undoubtedly read out loud to many listeners in public places. These included any place where the woodcuts could be hung on walls over wainscoting, yet low enough to be read. The tavern within a kermis print was thus experienced through looking and listening, if not looking and reading. ${ }^{65}$ The tavern was entertainment, and it recreated the entertainment of kermis.

63 Geisberg, German Single-Leaf Woodcut, vol. 1 (Barthel Beham), 144-49, Stanza 9:

Vnd der pösz Liendl von ganckhofen

Der het sich gantz plindt vol gesoffen

Der dantzet mit der Spindel Cristen

Die het wol dreytzemal gefisten.

Stanza 19:

Vom Potenstain der Esels miller

Der war am dysch der gröst Füller

Mit mayer Gred auch vmhin nülpt

Vnd hertzet sie das sie ergülpt.

64 Ibid., Stanza 3:

Der Weyn wart also knollet druncken

Das jr vil vnther Penck suncken

Sich huben grosz gröltzen vnd Speyen

Ein Kallen/singen/Juchtzen/schreyen.

65 For reading practices in the sixteenth century, see my "Paper Festivals," 347-8. 
Beham also showcases before the tavern a man lying on a bench in the Large Kermis where he vomits a full stream onto the ground, as a dog eagerly samples the fresh issue. Beham underscores the effects of wine for this drinker through trellis and grapes. But here, too, Beham links the emblem of vomiting man and dog with drunkenness in other ways. The man and dog together visualize the contemporary proverb, the "drunken matins" (die truncken Metten), which ironically refers to the vomit of a drunkard as singing in church. The expression is included in both visual and textual form on the title page with woodcut illustration to a pamphlet entitled A New Song. The Song is Called the Drunken Matins, which was printed at Nuremberg in the 1530s. ${ }^{66}$ Sebastian Franck explains the expression in his book of proverbs from 1541: the drunken matins results from drinking so much that Bacchus throws the drinker under a bench where the drinker begins to sing the drunken matins with long notes (a euphemism for vomiting). The result is that all dogs and pigs run to the drinker and gobble the song and the matins he produces. Franck calls such singing of the drunken matins debauchery. ${ }^{67}$

Beham's image of a drunken man can be seen to have functioned on at least three levels - as visualizations of the third (phlegmatic) effect of wine, the sin of gluttony, and a proverbial expression. So understood, the bread placed over the drunkard's head in the Large Kermis appears to ironically stand in for a halo. The moralizing association of gluttony for the proverb appears to parallel the kinds of meanings understood by humanists and civic and local authorities in early sixteenth-century Germany who believed drinking was such a widespread social problem that they rallied against it. Franck summed up such attitudes when he stated that, "More people die from excessive eating and drinking than from the sword." 68

Taverns were clearly the locus of a variety of experiences that viewers interpreted according to their own subjective set of responses. Such responses ranged from enjoyment and laughter to earnest moralizing and revulsion. On one hand, Beham's print emphasizes the shared outlook of the population at large, espe-

66 Ein newes Lied: Das lied ist die truncken Metten genant/Ist manchem guten gsellen wol erkant (Nuremberg: Hans Guldenmund, ca. 1530s). The title page woodcut is illustrated in Stewart, "Paper Festivals," figure 12.

67 Sebastian Franck, Sprichwörter (Frankfurt am Main: Christian Egenolff, 1541), part 2, fol. 148v: "O das ist dann ein grosse ehr ... under die banck wirfft, dz er anfahet die truncken mettin mit den langen noten zu singen, dasz all hund vnd sew zulauffen, vnd sich des gesangs vnd der mettin frewen." On the drunken matins expression, see Stewart, "Paper Festivals," 340-43.

68 "Es sterben mehr leut von fressen vnnd sauffen, dann vom schwerd." K. Christoffel, Durch die Zeiten strömt der Wein: Die wunderbare Historie des Weins (Hamburg, 1957), 226; Franck, Sprichwörter, part 2, fol. 162. 
cially the rural one that enjoyed kermis because of its potential for drink and other secular delights centered around taverns. At the same time, Beham's work also emphasizes the views of Nuremberg's small elite, comprising city clergy and council members, who viewed kermis as unchristian and heavy drinking as unfavorable at such religious festivals where the church, not the tavern, should predominate.

The kermis prints designed by Beham and his German contemporaries, and the images of taverns within them, served manifold purposes and reached large audiences. Descriptive, entertaining, and moralizing, the kermis woodcuts created in Nuremberg codify and perpetuate a world of celebration, conflict and aggression, and of occasional excessive drinking. The iconographic strategies outlined here indicate that Sebald Beham intentionally created prints that drew on society and its festivals, at the same time undergoing reevaluation and attempts at reform, as a slow and ongoing process spurred by the Lutheran Reformation at Nuremberg. Such festivals and social practices were centered around the tavern and were still alive, thriving, and extremely popular, despite criticisms. It is the prevalence and popularity of those tavern- and inn-centered festivals, as well as contemporary criticisms of them, that we see in the prints themselves, works that have helped stretch our understanding of the meanings and functions of tavern and inn in the sixteenth century. 